Down in New Orleans 


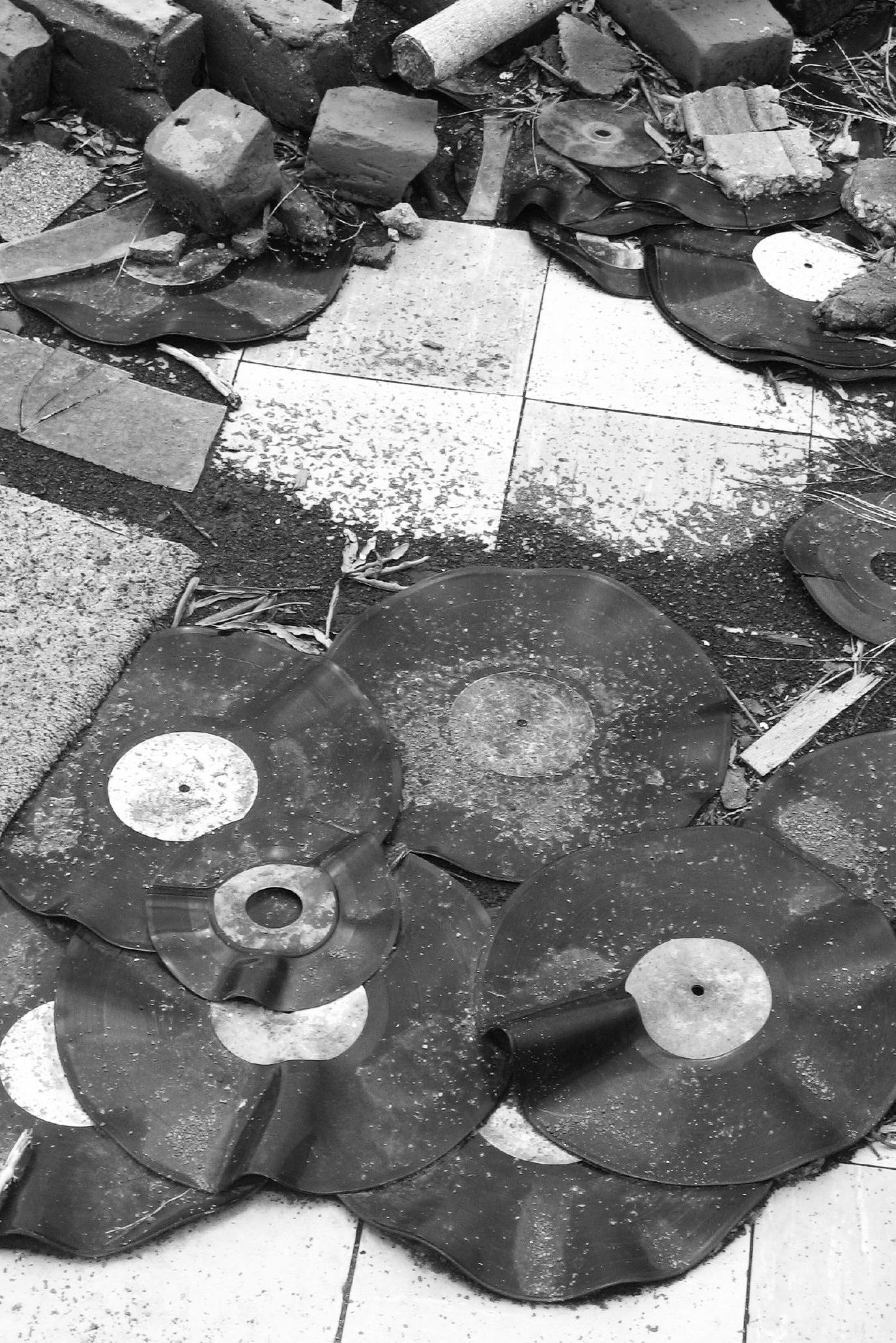




\title{
Down in New Orleans
}

Reflections from a Drowned City

\author{
Billy Sothern
}

Photographs by Nikki Page

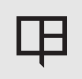

UNIVERSITY OF CALIFORNIA PRESS

Berkeley Los Angeles London 
The publisher gratefully acknowledges the generous contribution to this book provided by the African American Studies Endowment Fund of the University of California Press Foundation, which is supported by a major gift from the George Gund Foundation.

University of California Press, one of the most distinguished university presses in the United States, enriches lives around the world by advancing scholarship in the humanities, social sciences, and natural sciences. Its activities are supported by the UC Press Foundation and by philanthropic contributions from individuals and institutions. For more information, visit www.ucpress.edu.

University of California Press

Berkeley and Los Angeles, California

University of California Press, Ltd.

London, England

(C) 2007 by The Regents of the University of California

Library of Congress Cataloging-in-Publication Data

Sothern, Billy, I977-

Down in New Orleans : reflections from a drowned city / Billy Sothern; with photographs by Nikki Page.

p. $\quad \mathrm{cm}$.

Includes bibliographical references and index. ISBN: 978-0-520-25 I49-6 (cloth : alk. paper)

I. Hurricane Katrina, 2005. 2. Hurricanes-LouisianaNew Orleans. 3. Disaster victims-Louisiana-New Orleans. 4. Emergency management-Government policyUnited States. I. Title.

HV6 36 2005. L8 s68 2007

$976.3^{\prime} 35064-\mathrm{dc2} 2$

2007000213

Manufactured in the United States of America
$\begin{array}{llllllllll}\text { I6 } & \text { I5 } & \text { I4 } & \text { I3 } & \text { I2 } & \text { II } & \text { IO } & 09 & 08 & 07\end{array}$
I0 $9 \begin{array}{llllllllll} & 9 & 8 & 7 & 6 & 5 & 4 & 3 & 2 & \text { I }\end{array}$

This book is printed on Natures Book, which contains $50 \%$ post-consumer waste and meets the minimum requirements of ANSI/NIso Z39.48-I 992 (R I997) (Permanence of Paper). 
For Helen Hill and Paul Gailiunas, two of the finest New Orleanians, and our struggling but beautiful city, inestimably poorer in their absence 

Times are not good here. The city is crumbling into ashes. It has been buried under a lava flood of taxes and frauds and maladministrations so that it has become only a study for archaeologists. Its condition is so bad that when I write about it, as I intend to do soon, nobody will believe I am telling the truth. But it is better to live here in sackcloth and ashes than to own the whole state of Ohio.

Lafcadio Hearn, letter to a friend in Cincinnati in 1879 , after living in New Orleans for two years through the height of a yellow fever epidemic

To love. To be loved. To never forget your own insignificance. To never get used to the unspeakable violence and the vulgar disparity of life around you. To seek joy in the saddest places. To pursue beauty to its lair. To never simplify what is complicated or complicate what is simple. To respect strength, never power. Above all, to watch. To try and understand. To never look away. And never, never, to forget.

Arundhati Roy, The End of Imagination 
